\title{
Perbandingan Masalah Psikososial pada Remaja Obes dan Gizi Normal Menggunakan Pediatric Symptom Checklist [PSE]-17
}

\author{
Endah Pujiastuti, Eddy Fadlyana, Herry Garna \\ Departemen/SMF Ilmu Kesehatan Anak FK Universitas Padjadjaran/RS Dr. Hasan Sadikin, Bandung
}

\begin{abstract}
Latar belakang. Obesitas pada anak merupakan faktor penting karena cenderung meningkat dan dapat berpotensi sebagai penyebab berbagai konsekuensi medis serta masalah psikososial. Remaja obes cenderung mengalami rasa rendah diri, penghargaan diri yang buruk, depresi, mengalami kesulitan di sekolah, dan kesulitan belajar dibandingkan dengan remaja dengan status gizi normal.

Tujuan. Mengetahui perbandingan masalah psikososial antara remaja obes dan remaja status gizi normal dengan menggunakan kuesioner pediatric symptom checklist (PSC)-17, suatu kuesioner yang telah tervalidasi untuk mendeteksi masalah psikososial pada anak.

Metode. Rancangan analitik dengan metode potong silang, dilakukan pada bulan Mei-1 Juli 2011 di Sekolah Menengah Pertama Negeri 14 Bandung. Subjek penelitian adalah siswa usia 12-16 tahun yang dipilih secara berurutan (consecutive sampling), terdiri atas 31 remaja obes dan gizi normal. Indeks massa tubuh didapat dari pengukuran tinggi badan dan berat badan, kemudian dikelompokkan menjadi status gizi obes (>+3SD) dan gizi normal (-2 sampai +2 SD). Subjek mengisi kuesioner PSC-17 yang berisi beberapa pertanyaan mengenai variabel masalah psikososial, yaitu internalisasi, eksternalisasi, dan masalah perhatian. Uji statistik dengan chi-square test untuk perbandingan kedua kelompok.

Hasil. Terdapat 15/31 remaja obes dan 5/31 remaja gizi normal mengalami masalah psikososial ( $\mathrm{p}=0,007)$. Analisis aspek masalah psikososial kuesioner PSC memperlihatkan perbedaan bermakna mengenai masalah internalisasi antara kedua kelompok ( $\mathrm{p}=0,007)$.

Kesimpulan. Masalah psikososial kelompok remaja obes lebih tinggi dibandingkan dengan kelompok remaja gizi normal. Sari Pediatri 2013;15(4):201-6.
\end{abstract}

Kata kunci: masalah psikososial, obes, remaja

Alamat korespondensi:

Dr. Eddy Fadlyana, Sp.A(K). Bagian/SMF Ilmu Kesehatan Anak FK Unpad/Rumah Sakit Dr. Hasan Sadikin Jl. Pasteur No. 38 Bandung 40163, Indonesia. Telp. (022) 2035957. E-mail: edfadlyana@yahoo.com

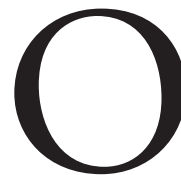

besitas mulai menjadi masalah kesehatan di seluruh dunia, bahkan WHO menyatakan bahwa obesitas sudah merupakan epidemi global dan merupakan problem kesehatan yang harus segera ditangani. Prevalensi overweight serta obesitas terus meningkat dan saat 
ini diperkirakan lebih dari 100 juta penduduk dunia menderita obesitas. ${ }^{1}$ Di Indonesia, prevalensi obesitas juga telah mencapai tingkat membahayakan. Berdasarkan data Survei Kesehatan Nasional (Susenas) ${ }^{2}$ tahun 2005, prevalensi gizi lebih 3,4\%, sedangkan berdasarkan data Riset Kesehatan Dasar (Riskesdas) ${ }^{3}$ tahun 2007, prevalensi berat badan berlebih anak usia 6-14 tahun pada laki-laki 9,5\% dan pada perempuan 6,4\%. Angka ini hampir sama dengan estimasi WHO prevalensi obesitas $10 \%$ pada anak usia 5-17 tahun.

Obesitas pada anak berisiko tinggi menjadi obesitas pada masa dewasa dan berpotensi menjadi penyebab berbagai penyakit kardiovaskular dan metabolik. ${ }^{4}$ Dampak lain yang juga penting, yaitu dampak terhadap tumbuh kembang terutama aspek psikososial karena untuk tumbuh kembang secara optimal selain kesehatan fisik juga diperlukan kesehatan mental. ${ }^{5}$ Reck $\mathrm{dkk}^{6}$ dalam penelitiannya menggunakan child behaviour checklist (CBCL) menyatakan 46,6\% anak obes mengalami gangguan psikososial. Penelitian lain oleh Riza $\mathrm{dkk}^{7}$ yang dilakukan di Solo dengan menggunakan kuesioner pediatric symptom checklist (PSC)-35 didapatkan prevalensi gangguan psikososial pada anak obes $11,6 \%$. Penelitian tersebut menyatakan bahwa anak obes lebih banyak mengalami masalah psikososial dibandingkan anak status gizi normal. Sedangkan Kim $\mathrm{dkk}^{8}$ dengan menggunakan CBCL menyatakan hal yang berbeda, yaitu tidak terdapat hubungan berat badan dan tinggi badan dengan masalah psikososial.

Penelitian ini bertujuan untuk mengetahui perbandingan masalah psikososial antara remaja obes dan remaja status gizi normal dengan menggunakan kuesioner (PSC)-17. Penelitian sebelumnya untuk mengetahui masalah psikososial pada remaja obes menggunakan kuesioner CBCL dan PSC-35, dan belum ada yang menggunakan PSC-17. Harahap dkk menyatakan bahwa PSC17 dapat digunakan sebagai alat skrining masalah psikososial pada anak dengan sensitivitas 69,2\% dan spesifisitas $95,6 \%$.

\section{Metode}

Desain penelitian rancangan potong lintang dilaksanakan pada bulan Mei sampai Juli 2011. Pengambilan subjek dilakukan secara consecutive sampling pada remaja obes dan gizi normal di Sekolah Menengah
Pertama Negeri 14, Bandung. Subjek penelitian remaja laki-laki dan perempuan berusia 12-16 tahun yang memenuhi kriteria inklusi untuk kelompok dengan status gizi obes (IMT/U >+3SD), serta remaja laki-laki dan perempuan sehat dengan status gizi baik yang orangtuanya telah menyetujui keikutsertaan anaknya dalam penelitian setelah diberi penjelasan dan menandatangani persetujuan (informed consent). Perhitungan besar sampel ditentukan berdasarkan rumus besar sampel untuk menguji dua proporsi, dan didapatkan besar sampel masing-masing kelompok 31 subjek. Kriteria eksklusi adalah remaja yang menderita penyakit kronik (thalassemia, tuberkulosis) dan mempunyai orangtua tunggal atau berpenyakit mental. Data diperoleh melalui anamnesis, pemeriksaan antropometris, dan pengisian kuesioner PSC-17.

Pediatric symptom checklist-17 merupakan alat yang digunakan untuk mengukur masalah psikososial berupa kuesioner terdiri atas 17 pertanyaan. Tujuhbelas pertanyaan yang dibagi menjadi subskala internalisasi, terdiri atas 5 pertanyaan, subskala eksternalisasi 7 pertanyaan, dan subskala perhatian 5 pertanyaan, masing-masing pertanyaan memiliki skor 0,1 , dan 2 . Skor masing-masing subskala tersebut dijumlahkan dan jumlah skor tersebut dijadikan skor total. Kuesioner ini dirancang untuk mengenali masalah kognitif, emosi, dan perilaku sehingga intervensi yang tepat dapat segera diinisiasi. Dicurigai terdapat masalah psikososial jika jumlah skor internalisasi $\geq 5$, jumlah skor eksternalisasi $\geq 7$, jumlah skor perhatian $\geq 7$, atau skor total $\geq 15$. Penelitian telah mendapat persetujuan dari Komite Etik Penelitian Kesehatan FK Universitas Padjadjaran-RS Dr. Hasan Sadikin Bandung.

Analisis statistik dilakukan dengan chi-square test untuk perbandingan dua kelompok. Kemaknaan hasil uji ditentukan dengan $\mathrm{p}<0,05$. Piranti lunak SPSS statistic ver. 17.0 (Windows) digunakan dalam analisis data.

\section{Hasil}

Penelitian melibatkan 62 subjek yang terdiri atas 31 remaja obes dan 31 remaja gizi normal berusia 12-16 tahun. Karakteristik umum orangtua maupun subjek penelitian tidak menunjukkan perbedaan bermakna. Tingkat pendidikan dan pendapatan orangtua remaja obes tidak menunjukkan perbedaan yang bermakna 
secara statistik dibandingkan dengan remaja status gizi normal (Tabel 1). Jumlah anggota keluarga pada remaja obes dan remaja status gizi normal juga tidak menunjukkan perbedaan. Semua subjek tinggal bersama kedua orangtua, tidak didapatkan adanya riwayat perceraian orangtua, baik pada remaja obes maupun remaja dengan status gizi normal, juga tidak didapatkan riwayat penyakit psikis pada semua orangtua.

Karakteristik umum kelompok subjek penelitian,

Tabel 1. Karakteristik orangtua dan subjek penelitian

\begin{tabular}{|c|c|c|}
\hline \multirow[t]{2}{*}{ Karakteristik orangtua } & $\begin{array}{c}\text { Remaja } \\
\text { obes }\end{array}$ & $\begin{array}{c}\text { Remaja } \\
\text { gizi } \\
\text { normal }\end{array}$ \\
\hline & $\mathrm{n}$ & $\mathrm{n}$ \\
\hline \multicolumn{3}{|l|}{ Pendidikan ayah } \\
\hline $\mathrm{SD}$ & 0 & 0 \\
\hline SLTP & 1 & 4 \\
\hline SLTA & 7 & 13 \\
\hline D3 & 6 & 3 \\
\hline$S-1 / S-2$ & 17 & 11 \\
\hline \multicolumn{3}{|l|}{ Pendidikan ibu } \\
\hline $\mathrm{SD}$ & 0 & 1 \\
\hline SLTP & 1 & 6 \\
\hline SLTA & 14 & 11 \\
\hline D3 & 5 & 5 \\
\hline$S-1 / S-2$ & 11 & 8 \\
\hline \multicolumn{3}{|l|}{ Penghasilan keluarga (rupiah) } \\
\hline$<1.160 .000$ & 3 & 9 \\
\hline $1.160 .000-2.885 .000$ & 15 & 13 \\
\hline$>2.885 .000$ & 13 & 9 \\
\hline \multicolumn{3}{|c|}{ Jumlah anggota keluarga (orang) } \\
\hline$\leq 4$ & 15 & 13 \\
\hline$>4$ & 16 & 18 \\
\hline \multicolumn{3}{|l|}{ Usia (tahun) } \\
\hline $12-13$ & 1 & 3 \\
\hline $13-14$ & 30 & 28 \\
\hline \multicolumn{3}{|l|}{ Jenis kelamin } \\
\hline Laki-laki & 19 & 14 \\
\hline Perempuan & 12 & 17 \\
\hline
\end{tabular}

baik usia maupun jenis kelamin tidak berbeda. Angka kejadian masalah psikososial lebih tinggi pada kelompok remaja obes daripada remaja status gizi normal (Tabel 2). Pada kelompok remaja obes terdapat 15/31 orang mempunyai masalah psikososial. Kelompok remaja dengan status gizi normal terdapat 5/31 orang mempunyai masalah psikososial. Kelompok remaja obes mempunyai prevalensi masalah psikososial lebih tinggi yang bermakna dibandingkan dengan kelompok remaja gizi normal $(\mathrm{p}=0,007)$.

Analisis mengenai aspek masalah psikososial yang terdapat dalam kuesioner PSC, yaitu subskala internalisasi, eksternalisasi, dan perhatian (Tabel 4). Pada kelompok remaja obes didapat 15/31 mengalami masalah internalisasi, 1/31 eksternalisasi, dan 1/31 masalah perhatian. Kelompok remaja status gizi normal 5/31 mengalami masalah internalisasi, tetapi tidak satupun mengalami masalah eksternalisasi dan masalah perhatian. Terdapat perbedaan yang bermakna mengenai masalah internalisasi pada kedua kelompok $(p=0,007)$. Tidak didapatkan perbedaan yang bermakna mengenai aspek eksternalisasi dan perhatian pada kedua kelompok $(\mathrm{p}=0,50 ; \mathrm{p}=1,00)$. Masalah internalisasi lebih dominan terjadi, yaitu merasa sedih, tidak bahagia, mudah putus asa, cemas, khawatir, cenderung menyalahkan diri sendiri, dan kurang gembira. Pada kelompok remaja obes terdapat 9/31 mempunyai skor total kuesioner PSC $\geq 15$ dan 22/31 mempunyai skor total kuesioner PSC $<15$. Pada kelompok remaja status gizi normal tidak ada satupun yang mempunyai skor total kuesioner PSC $\geq 15$. Terdapat perbedaan bermakna antara kedua kelompok $(\mathrm{p}=0,001)$.

\section{Pembahasan}

Kelompok remaja obes lebih banyak mengalami masalah psikososial dibandingkan remaja dengan gizi normal.

Tabel 2. Masalah psikososial remaja obes dan remaja status gizi normal

\begin{tabular}{lccc}
\hline & \multicolumn{3}{c}{ Kelompok } \\
\cline { 2 - 4 } & $\begin{array}{c}\text { Remaja obes } \\
(\mathrm{n}=31)\end{array}$ & $\begin{array}{c}\text { Remaja gizi normal } \\
(\mathrm{n}=31)\end{array}$ & Nilai $\mathrm{p}^{*}$ \\
\hline $\mathrm{Ya}$ & 15 & 5 & \\
Tidak & 16 & 26 & 0,007 \\
\hline
\end{tabular}

Keterangan: ${ }^{*}=\mathrm{Uji}$ chi-square 
Tabel 3. Aspek masalah psikososial remaja obes dan remaja gizi normal

\begin{tabular}{lccc}
\hline Aspek masalah psikososial & Remaja obes & Remaja gizi normal & Nilai p \\
\hline Internalisasi & & 5 & \\
$\quad$ Ya & 15 & 15 & 0,007 \\
$\quad$ Tidak & 16 & 0 & \\
Eksternalisasi & 1 & 31 & 0,313 \\
$\quad$ Ya & 30 & 0 & \\
$\quad$ Tidak & 1 & 31 & 0,313 \\
Perhatian & 30 & & \\
$\quad$ Ya & & 0 & 0,001 \\
$\quad$ Tidak & 9 & 31 & \\
Skor total $\geq 15$ & 22 & & \\
$\quad$ Ya & & & \\
$\quad$ Tidak & & &
\end{tabular}

Keterangan: $t=\mathrm{Uji}$ chi-square

Telah diketahui sebelumnya bahwa anak obes mudah mengalami gangguan psikososial karena memiliki rasa percaya diri yang rendah, persepsi diri yang negatif, dan rasa rendah diri, serta menjadi bahan ejekan teman-temannya. ${ }^{11}$ Gangguan psikososial pada anak obes dapat disebabkan oleh dua faktor, yaitu faktor internal dan faktor eksternal. Faktor internal merupakan faktor yang berasal dari anak itu sendiri, yaitu keinginan untuk menguruskan badan dan merasa berbeda dengan anak lain sehingga anak obes mempunyai rasa percaya diri yang rendah dan mudah mengalami depresi. Faktor eksternal merupakan faktor yang berasal dari lingkungan yang memberikan "stigma" pada anak obes yang dianggap sebagai anak yang malas, bodoh, dan lamban. ${ }^{5,12}$ Lingkungan merupakan keseluruhan fenomena fisik atau sosial yang memengaruhi atau dipengaruhi perkembangan remaja, meliputi lingkungan keluarga, sekolah, teman sebaya, dan masyarakat. ${ }^{11}$ Faktor keluarga yang memengaruhi perkembangan anak/remaja, yaitu fungsi keluarga, pola hubungan orangtua-anak, serta kelas sosial, dan status ekonomi.

Dari hasil penelitian, didapat perbedaan skor total PSC antara kedua kelompok. Kelompok remaja obes mempunyai skor PSC lebih tinggi dibandingkan dengan kelompok remaja gizi normal. Hal tersebut menunjukkan bahwa masalah psikososial pada kelompok remaja obes lebih tinggi dibandingkan dengan kelompok remaja gizi normal. Kelompok remaja obes memiliki skor total PSC rata-rata 11 dengan rentang $0-19$. Kelompok remaja gizi normal memiliki skor total PSC rata-rata 9 dengan rentang 4-14.

Penilaian masing-masing aspek dalam PSC, yaitu internalisasi, eksternalisasi, dan perhatian, kelompok remaja obes yang mengalami masalah internalisasi lebih tinggi dibandingkan dengan remaja status gizi normal. Masalah internalisasi lebih dominan terjadi disebabkan usia remaja selain terjadi perkembangan fisik, juga terjadi perkembangan sosial, emosi, moral, dan kepribadian. Pencapaian tujuan pola sosialisasi dewasa maka remaja harus membuat banyak penyesuaian baru, yaitu penyesuaian diri dengan meningkatnya pengaruh kelompok sebaya, perubahan dalam perilaku sosial, pengelompokan sosial yang baru, nilai-nilai baru dalam seleksi persahabatan, nilai-nilai baru dalam dukungan dan penolakan sosial, serta nilai-nilai baru dalam seleksi pemimpin. ${ }^{13}$ Masa remaja tersebut dinyatakan sebagai periode "badai dan tekanan", yaitu suatu masa ketegangan emosi meninggi sebagai akibat dari perubahan fisik dan kelenjar. Perubahan emosi yang meninggi dikarenakan tekanan sosial dan menghadapi kondisi baru. Masa remaja juga mengalami perkembangan moral, yaitu berusaha memelajari apa yang diharapkan oleh kelompoknya, kemudian membentuk perilaku agar sesuai dengan harapan sosial tanpa terus dibimbing, diawasi, didorong, dan diancam hukuman seperti yang dialami waktu masa anak-anak. ${ }^{15}$ Masa remaja juga merupakan masa perkembangan kepribadian. Banyak remaja menggunakan standar kelompok sebagai dasar konsep 
mereka mengenai kepribadian “ideal”. Tidak banyak remaja yang merasa dapat mencapai gambaran yang ideal dan mereka yang tidak berhasil ingin mengubah kepribadian mereka. ${ }^{15}$ Selain itu, remaja juga mulai mempunyai stigmatisasi atas dirinya, misalnya rasa tidak puas dengan penampilannya, bentuk tubuhnya, dan mulai merasa malu sehingga berkembang perasaan yang dapat memengaruhi bagaimana mereka menilai dirinya. Hal tersebut dapat menyebabkan kecemasan, depresi, dan masalah somatik pada remaja.

Remaja obes ternyata tidak selalu menderita masalah psikososial. Beberapa remaja obes mempunyai rasa percaya diri seperti remaja normal lainnya. Kami mendapatkan 16 dari 31 remaja obes tidak menderita masalah psikososial. Israel dan Ivanova ${ }^{14}$ menyatakan bahwa anak dan remaja obes dengan rasa percaya diri normal menggunakan metode kompensasi sebagai perlindungan terhadap timbulnya rasa percaya diri yang rendah. Metode kompensasi tersebut, yaitu discounting dan distortion. Discounting, yaitu menempatkan hal-hal yang merupakan kelebihan mereka di atas penilaian terhadap bentuk tubuhnya sendiri. Distortion, yaitu meningkatkan persepsi mengenai kompetensi mereka dengan mengesampingkan bentuk tubuh atau berat badan. Remaja obes laki-laki dan perempuan tidak menekankan rasa percaya diri mengenai bentuk fisiknya dan lebih menekankan rasa percaya diri mengenai hal lain untuk mempertahankan rasa percaya diri mereka. Penggambaran bahwa faktor psikososial berperan penting dibandingkan dengan keterbatasan fungsional dari obesitas itu sendiri. Dukungan sosial pada remaja obes akan memberikan dampak yang lebih baik dibandingkan dengan hanya terfokus pada obesitas itu sendiri sebagai penyebab terjadinya masalah psikososial. ${ }^{15}$ Penelitian lebih lanjut diperlukan untuk mengetahui mengapa beberapa remaja obes lebih mudah mengalami rasa percaya diri yang rendah dibandingkan dengan remaja lainnya.

Penelitian kami mempunyai keterbatasan karena tidak dilakukan evaluasi dengan alat penilaian standar untuk mengetahui penyakit psikis pada orangtua. Data yang diperoleh berdasarkan keterangan dari hasil pengisian kuesioner.

\section{Kesimpulan}

Kami mendapatkan remaja obes memiliki masalah psikososial lebih tinggi dibandingkan dengan remaja gizi normal. Skrining masalah psikososial pada remaja obes dapat dijadikan sebagai salah satu pedoman umum dalam kebijakan tata laksana, sehingga perawatan medis dini dan efektif dapat diambil secara klinis untuk mencegah komplikasi lebih lanjut.

\section{Daftar pustaka}

1. World Health Organization. Obesity: preventing and managing the global epidemic. Geneva: WHO Technical Report series; 2003.

2. Departemen Kesehatan RI Survey Kesehatan Nasional (Susenas). Jakarta: Departemen Kesehatan RI; 2005.

3. Departemen Kesehatan RI Riset Kesehatan Dasar (Riskesdas). Jakarta: Departemen Kesehatan RI; 2007.

4. Barlow SE and the Expert Committee. Expert committee recommendations regarding the prevention, assessment, and treatment of child and adolescent overweight and obesity: summary report. Pediatrics 2007;120:164-92.

5. Puhl RM, Brownell KD. Psychosocial origins of obesity stigma: toward changing a powerful and pervasive bias. Obesity Rev 2003;4:213-27.

6. Reck UK, Korsten K, Haeberle K, Hauschild KK, Dickhuth HH, Schulz E. The psychosocial situation of obese children: psychological factors and quality of life. Psych Res Behav Manage 2009;2:23-9.

7. Riza M, Lestari DL, Murtikarini S, Hidayah D, Martuti S. Prevalensi dan beberapa faktor yang mempengaruhi gangguan psikososial pada anak obes usia sekolah dasar di kotamadya Surakarta. Cermin Dunia Kedok 2007;34:304-6.

8. Kim B, Park MJ. The influence of weight and height status on psychological problems of elementary school children through child behavior checklist analysis. Yonsei Med J 2009;50:340-4.

9. Harahap DF, Sjarif DR, Soedjatmiko, Widodo DP, Tedjasaputra MS. Identification of emotional and behavior problems in obese children using child behavior checklist (CBCL) and 17-items pediatric symptom checklist (PSC-17). Pediatr Indones 2010;50:42-8.

10. Villa G, Zipper E, Dabbas M, Bertrand C, Robert JJ, Ricour C, dkk. Mental disorders in obese children and adolescents. Psychosom Med 2004;66:387-94.

11. Janssen I, Craig W, Boyce W. Association between overweight and obesity with bullying behaviours in school-aged children. Pediatrics 2004;113:1187-94.

12. Sjarif DR. Obesitas pada anak dan permasalahannya. Dalam: Trihono PP, Pudjiarto PS, Sjarif DR, penyunting. 
Pendidikan kedokteran berkelanjutan ilmu kesehatan anak XLV. Hot topics in pediatrics II. Jakarta: Balai Penerbit FKUI; 2002.h.219-34.

13. Hurlock EB. Perkembangan suatu pendekatan sepanjang rentang kehidupan. Edisi ke-5. Jakarta: Erlangga; 2004.
14. Israel AC, Ivanova MY. Global and dimensional selfesteem in preadolescent and early adolescent children who are overweight: age and gender differences. Int J Eat Disord 2002;31:424-9.

15. Yusuf S. Psikologi perkembangan anak dan remaja. Bandung: PT Remaja Rosdakarya; 2010. 